\title{
Surface Engineering Effect on Optimizing Hydrogenation Timing of Green Hydrogenated Chitosan-Mediated CuO (H-Cht-CuO) for Cashew-kernel-oil Hydrogenation
}

\author{
Joshua Lelesi Konne ${ }^{1, \text { * }}$, Hamilton Amachree Akens ${ }^{2}$, Arinze Amauche Uwaezuoke ${ }^{1}$, \\ Achu Golden Chiamaka ${ }^{1}$ \\ ${ }^{1}$ Department of Chemistry, Rivers State University, Port Harcourt, Nigeria \\ ${ }^{2}$ Department of Chemistry, Federal University, Otuoke, Nigeria
}

Email address:

konne.joshua@ust.edu.ng (J. L. Konne)

${ }^{*}$ Corresponding author

To cite this article:

Joshua Lelesi Konne, Hamilton Amachree Akens, Arinze Amauche Uwaezuoke, Achu Golden Chiamaka. Surface Engineering Effect on Optimizing Hydrogenation Timing of Green Hydrogenated Chitosan-Mediated CuO (H-Cht-CuO) for Cashew-kernel-oil Hydrogenation. Modern Chemistry. Special Issue: Green Synthesis of Nanostructured Materials and Their Catalytic Applications.

Vol. 7, No. 3, 2019, pp. 73-79. doi: 10.11648/j.mc.20190703.15

Received: August 22, 2019; Accepted: September 20, 2019; Published: September 29, 2019

\begin{abstract}
The effect of polycrystallite surface engineering on the time required to fully hydrogenate green chitosanmediated $\mathrm{CuO}$ to form hydrogenated chitosan-mediated $\mathrm{CuO}(\mathrm{H}-\mathrm{Cht}-\mathrm{CuO})$ as well as the catalytic properties of both $\mathrm{CuO}$ and $\mathrm{H}-\mathrm{Cht}-\mathrm{CuO}$ have been investigated. The prepared chitosan mediated $\mathrm{CuO}$ was obtained from the reaction of copper (II) sulphatepentahydrate with green alkali (aqueous extract of ripe plantain peel ash) via sol-gel technique (chitosan-gel mediated) and heated at $550^{\circ} \mathrm{C}$ for $6 \mathrm{~h}$. The resultant sample was divided into two portions. The first was used as the control experiment $(0 \mathrm{~min})$ while the second was hydrogenated at varying times of 2 to 8 mins to form the $\mathrm{H}-\mathrm{Cht}-\mathrm{CuO}$ samples. A second $\mathrm{CuO}$ (control) without chitosan was also synthesized for structural and surface morphological comparisons with the chitosanmediated using the XRD and SEM techniques, respectively. The XRD reflections showed differences in peak intensities with the chitosan-mediated having broader peaks while its SEM pores were 8.5 times larger than those of $\mathrm{CuO}$ (non chitosanmediated). UV-Vis analysis of the samples showed that the 2 mins $\mathrm{H}-\mathrm{Cht}-\mathrm{CuO}$ sample had the maximum absorptivity while $\mathrm{CuO}$ (control-chitosan mediated) had the least. Both samples were used as catalysts in the hydrogenation of Cashew kernel oil. The GC-MS results showed that the Oleic acid component was reduced from $84.36 \%$ to $0.06 \%$ and $0 \%$, Linoleic acid from $8.68 \%$ to $3.63 \%$ and $0 \%$ with increase in Stearic acid (saturated $\mathrm{C}_{18}$ ) from $4.88 \%$ to $34.97 \%$ and $84.76 \%$ by the $\mathrm{CuO}$ and $\mathrm{H}-$ Cht-CuO, respectively.
\end{abstract}

Keywords: Optimizing, Hydrogenation Timing, Chitosan-Mediated, Surface Engineering,

Cashew-Kernel-Oil Hydrogenation

\section{Introduction}

Cashew (Anacardiumoccidentale L.) is a native tree of Brazil and is widely cultivated as a potential commercial crop throughout the tropical climate regions particularly in Africa and Asia such as Kenya, Madagascar, Nigeria, India, Sri Lanka and Thailand [1]. It consists of the nuts containing an embryo and a false fruit commonly called cashew kernel/nut and cashew apple respectively [2].

Unprocessed cashew kernel oil is neutral and good for human because it is rich in unsaturated fatty acids $[3,4]$. The total saturated fatty acid in cashew kernel oil is $21.6 \%$ while total unsaturated fatty acid is $78.1 \%$. Oleic acid dominates the unsaturated fatty acid present in the oil to about $58.7 \%$ [5]. It is therefore used as an excellent food source which finds applications in flavourings and cooking of foods [6]; soap making [7]; preservative due to its moderate antimicrobial activity [8] and as supplementing vegetable oil [9].

Hydrogenation of vegetable oils is a very important 
operation in the industrial process of producing vegetable tallow, vegetable fats, margarines, and starting components for the cosmetic and chemical industry such as emulsifiers, soaps, creams, pastes, and similar substances [10]. Hydrogenation increases oxidation resistance, improves shelf life and changes the thermal behavior of the oil, making it suitable for specific uses [11].

Commonly used hydrogen catalysts include copper chromite, nickel, cobalt and the noble metals. Several catalysts for hydrogenation of oils known in the literature include $\mathrm{Cu} / \mathrm{SiO}_{2}$ [12]; $8 \% \mathrm{Cu} / \mathrm{SiO}_{2}$ [13]; $\mathrm{Ni} / \mathrm{SiO}_{2}$ [14] and $\mathrm{Pd} / \mathrm{SiO}_{2}$ [15] catalysts; $\mathrm{Ni} / \mathrm{Ru}$ mixture [16]. Reduced nickel is the most widely used catalyst by the vegetable oil industry, but copper, platinum, palladium and ruthenium are also effective.

The use of $\mathrm{CuO}$ as catalysts has received attention in recent times due to its high stability, super thermal conductivity and antimicrobial activity [17]. In addition, $\mathrm{CuO}$ showed high oleic acid selectivity when used as catalyst for vegetable oil hydrogenation [18-20]. Other applications include gas sensors [21]; high efficiency thermal conductivity material [22] and magnetic recording media [23].

The search for new, cheaper and nontoxic catalysts for the hydrogenation of vegetable oil is still ongoing. Recent works on the production and application of hydrogenated metal oxides $(\mathrm{ZnO}: \mathrm{H}$ and $\mathrm{CuO}: \mathrm{H})$ for insitu/enhanced hydrogenation reactions with vegetable oils have recorded better performances than the unhydrogenated [20, 24]. However, surface/morphological engineering as well as optimization of hydrogenation timing of these catalysts would be essential to minimize cost and time wastage during the catalyst hydrogenation process since previous work recommended longer hydrogenation timing for maximum hydrogen loading of the catalysts [20]. This research would therefore investigates the optimum hydrogenation timing of a surface-engineered $\mathrm{CuO}$ (synthesized chitosan-mediated green $\mathrm{CuO}$ ) and its application for the hydrogenation of cashew kernel oil while using the unhydrogenated chitosan-mediated $\mathrm{CuO}$ as the control experiment.

\section{Materials and Method}

\subsection{Extraction of Alkali from Ripe Plantain Peels}

Ripe plantain was bought from Mile 3 Market PortHarcourt. The fresh peels were removed, washed and were cut into smaller portions using cutter after which the peels were sun dried and milled. $270 \mathrm{~g}$ of the ripe plantain peels were weighed using Analytical weighing balance and ashed in a Murfle furnace at $550^{\circ} \mathrm{C}$ for $5 \mathrm{~h}$. Afterwards, the resultant $37.20 \mathrm{~g}$ ash was cooled to room temperature in a desiccator and thereafter dissolved in $500 \mathrm{~mL}$ distilled water. This was allowed to stand for two days to achieve complete extraction. The solution (green alkali) was filtered and the concentration determined titrimetrically as $0.67 \mathrm{M}$ upon reaction with $1 \mathrm{M}$ solution of hydrochloric acid $(\mathrm{HCl})$ with methyl orange as indicator.

\subsection{Extraction of Oil from Cashew Kernel}

Cashew nuts were purchased from Afor Oba Market in Anambra state. The nuts were cleaned, dried for two days and were roasted. A Cutter was used to slit the nuts open and knife employed to remove the kernels immediately. The kernels were oven dried at $60{ }^{\circ} \mathrm{C}$ for $12 \mathrm{~h}$, the dried pellets were removed and milled into flour using a milling machine. The oil (240 g) was then extracted from $2000 \mathrm{~g}$ of the cashew kernel flour with n-Hexane using the solvent extraction method giving a $12 \%$ (percent) oil yield.

\subsection{Synthesis of Hydrogenated Chitosan Mediated Copper Oxide ( $\mathrm{H}-\mathrm{Cht}-\mathrm{CuO})$}

Chitosan mediated copper oxide $(\mathrm{CuO})$ was synthesized using the sol-gel technique in which $10 \mathrm{~mL}$ of $0.01 \mathrm{M}$ solution of copper sulphatepentahydrate $\left(\mathrm{CuSO}_{4} .5 \mathrm{H}_{2} \mathrm{O}\right)$ was dissolved in $20 \mathrm{~mL}$ chitosan gel solution (prepared by dissolving $2 \mathrm{~g}$ of chitosan in $1 \mathrm{~L}$ distilled water plus $15 \mathrm{~mL}$ acetic acid and stirred to form the gel). The chitosan-copper sulphate mixture was mixed with $10 \mathrm{~mL}$ of the extracted alkali. The mixture was stirred and the resultant precipitate $\mathrm{Cu}(\mathrm{OH})_{2}$, filtered and oven dried overnight at $80^{\circ} \mathrm{C}$. The dried flakes (mixture) were ashed in a murfle furnace at $550^{\circ} \mathrm{C}$ for $6 \mathrm{~h}$ to convert the copper hydroxide to copper (II) oxide $(\mathrm{CuO})$.

The chitosan-mediated $\mathrm{CuO}$ portion was hydrogenated using the method in literature [20]. Modification was in the use of different masses of $\mathrm{Mg}$ and timing of the reaction. Four small test tubes each was connected to a narrow delivery tube in direct exposure to $\mathrm{H}_{2}$ gas flow released from the action of different masses of magnesium metal $(0.50$, $1.00,1.50$ and $2.00 \mathrm{~g}$ ) at different time intervals of $2,4,6$, and 8 mins, respectively in a $15 \mathrm{~mL}$ aqueous $6 \mathrm{M} \mathrm{HCl}$ solution. The reaction was carried out using a corked Buchner flask. Each of the test tubes was clamped above a heating mantle operating at $50{ }^{\circ} \mathrm{C}$ during the reaction to enhance the rate of reaction due to elevated temperature effect.

\subsection{Hydrogenation of Extracted Cashew Kernel Oil Using Hydrogenated and Non-Hydrogenated Chitosan Mediated Copper Oxide Catalysts}

$4.00 \mathrm{~g}$ of the extracted cashew kernel oil was mixed with $24 \mathrm{~mL}$ tetrahydrofuran (THF) and transferred into a two neck round bottom flask containing $0.40 \mathrm{~g}$ of the synthesized hydrogenated chitosan mediated copper oxide, $\mathrm{H}-\mathrm{Cht}-\mathrm{CuO}$ (Figure 1) The solution was stirred under constant flow of hydrogen gas from a hydrogen gas cylinder at room temperature for $1 \mathrm{~h}$. This reaction process was repeated for the non-hydrogenated chitosan mediated copper oxide $(\mathrm{CuO})$. 


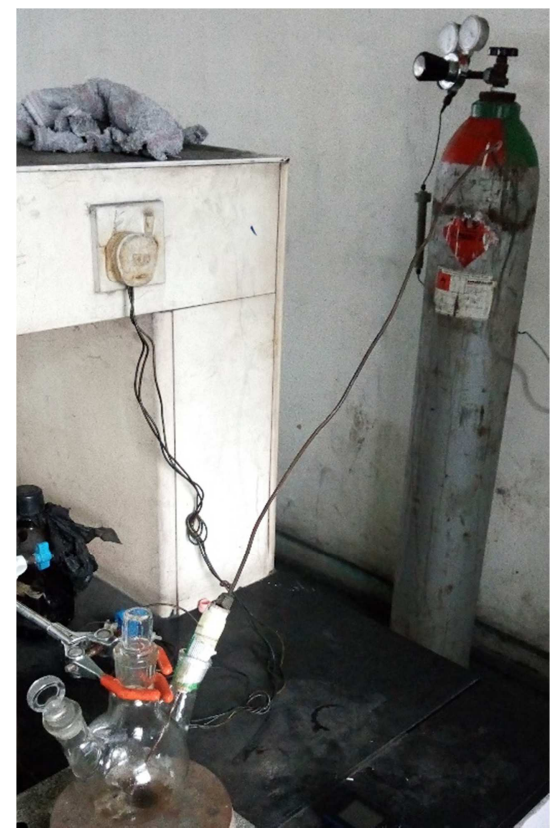

Figure 1. Hydrogenation of Cashew Kernel Oil with $\mathrm{CuO}$ and $\mathrm{H}-\mathrm{Cht}-\mathrm{CuO}$.

\subsection{Characterization}

\subsubsection{Structural (XRD and SEM) and UV-Vis Analyses of the Catalysts}

EMPYREAN model Powder X-ray diffractometer was used to analyze the sample structures between 2-theta 5 to $75^{\circ}$ with a step size of $0.02^{\circ}$ for the chitosan mediated control $(\mathrm{CuO})$ and the $\mathrm{CuO}$ without chitosan only due to the cost of analysis. In addition previous reports have shown that the presence of hydrogen do not alter the structural morphology of the samples. The same samples were used for SEM analysis. This was necessary to establish the morphological differences caused by sol-gel technique with chitosan while in the UV-Vis analysis, chitosan mediated copper oxide $(0$ mins) and the four hydrogenated forms of 2, 4, 6, and 8 mins were characterized using UV-Vis Spectroscopy. $0.05 \mathrm{~g}$ each of the catalysts was dissolved in $5 \mathrm{~mL}$ distilled water and scanned between $280 \mathrm{~nm}-700 \mathrm{~nm}$ using UV-Vis spectrophotometer with distilled water as the blank. A plot of absorbance against wavelength was used to identify the sample with the highest absorptivity to be used for the vegetable oil hydrogenation process as the catalyst while the chitosan mediated was used as the control.

\subsubsection{GC-MS of the Hydrogenated Cashew Kernel Oil}

Cashew kernel oil and hydrogenated cashew kernel oils (catalyzed by chitosan mediated and hydrogenated chitosan mediated copper oxide catalysts) were characterized using Gas Chromatography-Mass Spectroscopy (GC-MS). The AOAC method as reported in literature was used [25]. The method involved the solvent extraction of the fatty acids from the oil using methanolic sodium hydroxide solution, hexane and distilled water in which the upper organic phase is injected to the GC for analysis. The instrument used was Agilent 7890A (USA) coupled with flame-ionization detector (FID).

\section{Results and Discussions}

The XRD reflections of the synthesized $\mathrm{CuO}$ and chitosanmediated $\mathrm{CuO}$ are shown in Figure $2 \mathrm{a}$ and $\mathrm{b}$ respectively. These were indexed to the $\mathrm{CuO}$ and $\mathrm{Cu}_{2} \mathrm{O}$ (impurity) phases reported in literature [20]. It was also observed that there was more peak broadening probably due to particle size reduction in the chitosan-mediated $\mathrm{CuO}$ (Figure 2b) than in the $\mathrm{CuO}$ without chitosan (Figure 2a). Particle size estimation with Sherrers' formula should have confirmed the differences but was not evaluated due to non-inclusion of Full Width at Half Maximum (FWHM) by the analyst as a result of software issues. The Figure also showed that the unlabeled peak (x) appeared more prominent in the chitosan-mediated than in the $\mathrm{CuO}$ without chitosan.

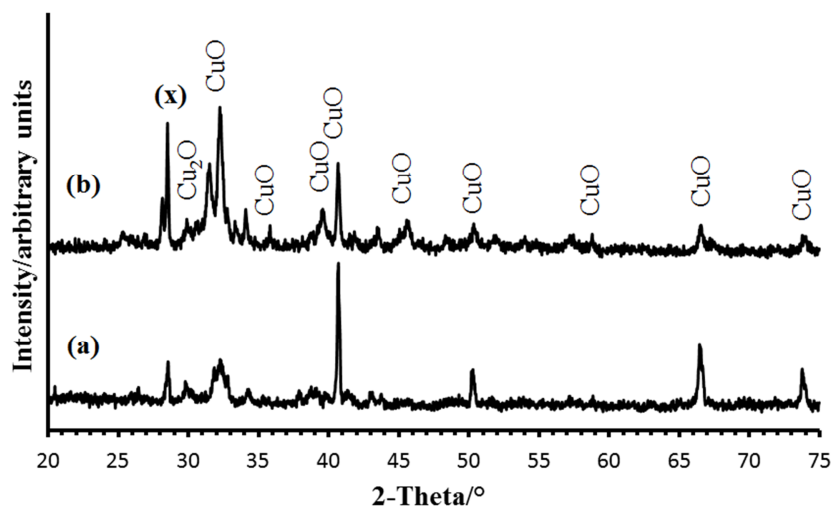

Figure 2. Shows the XRD reflections of (a) $\mathrm{CuO}$ and (b) chitosan-mediated $\mathrm{CuO}$ with minor impurity peak of $\mathrm{Cu}_{2} \mathrm{O}$ and an unknown peak, $x$.

SEM analysis was done in order to evaluate surface morphological differences between the $\mathrm{CuO}$ without chitosan and the chitosan-mediated $\mathrm{CuO}$ (Figure $3 \mathrm{a}$ and $\mathrm{b}$ ). The $\mathrm{CuO}$ without chitosan showed a flat porous surface while the chitosan-mediated $\mathrm{CuO}$ surface showed fewer but wider pores with rougher surfaces. The pore size of the latter was calculated to be 8.5 times larger than the former on length scales. This observation confirmed that surface engineering was achieved by the sol-gel synthesis with chitosan. The control $(\mathrm{CuO})$ porosity might be caused by the presence of other soluble elements (impurities) in the extracted alkali used as the addition of chitosan further widened the sizes of the pores.

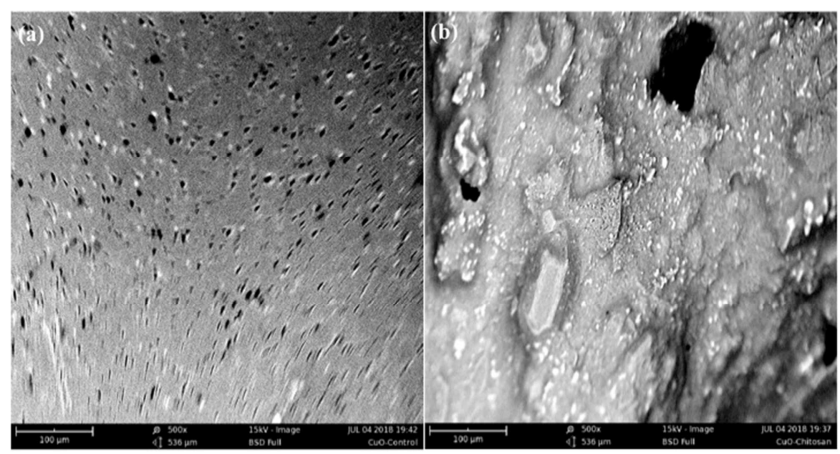

Figure 3. Showing the SEM micrographs of (a) $\mathrm{CuO}$ and (b) chitosanmediated $\mathrm{CuO}$. 
The observed higher porosity was achieved due to the ashing of the $\mathrm{CuO}$ precursor-chitosan matrix which left behind more porous $\mathrm{CuO}$ crystals with smaller particle sizes. This was responsible for the peak broadening observed on the XRD of the chitosan-mediated $\mathrm{CuO}$. Previous studies have reported morphological control/surface engineering via sol-gel (chitosan-mediated) route [26].

The optical absorbance characteristics of the chitosanmediated $\mathrm{CuO}$ portions that were hydrogenated as H-Cht$\mathrm{CuO}$ catalysts with different $\mathrm{H}$-loading concentrations and the non-hydrogenated chitosan-mediated $\mathrm{CuO}(0 \mathrm{~min})$ was measured using the UV-Vis as shown in Figure 4.

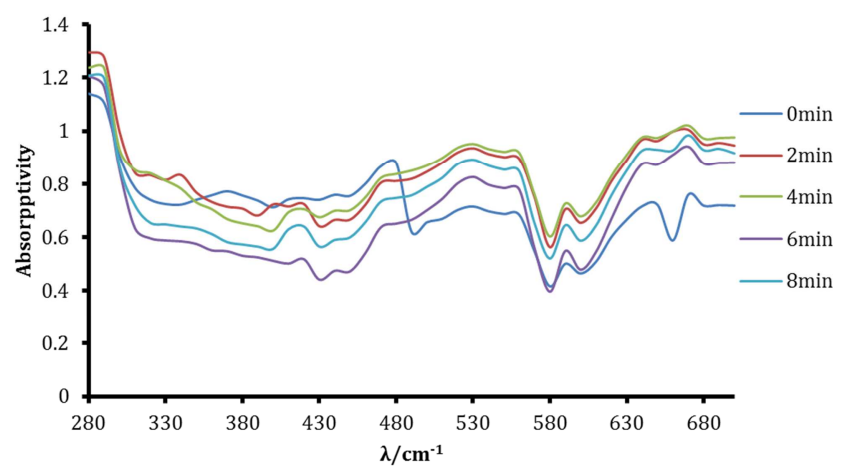

Figure 4. UV absorption spectra of chitosan-mediated $\mathrm{CuO}(0 \mathrm{~min})$ and hydrogenated-chitosan-mediated copper oxides ( $\mathrm{H}$-Cht-CuO) in which the samples absorbed at $280 \mathrm{~nm}$ absorptivity decreases sharply with increase in wavelength.

The 2 min H-Cht-CuO sample showed the highest absorptivity while the $0 \mathrm{~min}$ was the least among the five samples indicating that a possible saturation of $\mathrm{Cu}$ or $\mathrm{O}$ vacancies in the $\mathrm{CuO}$ was reached just in 2 mins of hydrogenation. Weak absorption bands with high intensities like these among non-stochiometric metal oxides have been linked to transitions due to ligand-metal charge transfer (LMCT). Here, oxygen anion may transfer an electron to complete the partially filled $3 \mathrm{~d}$ orbitals of $\mathrm{Cu}$ and this transfer is compensated by the presence of electrons from $\mathrm{H}$ atoms. This possibility was absent in the case of the non-hydrogenated $\mathrm{CuO}$ and might be responsible for its lowest absorptivity.

This is because hydrogen atoms substitute oxygen vacancies to form a four-fold coordination with $\mathrm{Cu}$ in the hydrogenated phases and $\mathrm{Cu}$ vacancies are being substituted by two H-atoms [24]. Previous report had suggested further hydrogenation of $\mathrm{CuO}$ beyond 8 mins to achieve maximum result but this result showed that with surface engineering of $\mathrm{CuO}$ through sol-gel synthesis with chitosan, maximum hydrogenation could be achieved in 2 mins as further hydrogenations disrupted the fully hydrogenated state leading to a decrease the absorptivity [20]. Other weak absorption peaks observed were at $410 \mathrm{~nm}, 470 \mathrm{~nm}, 560 \mathrm{~nm}, 590 \mathrm{~nm}$, $640 \mathrm{~nm}$, and $670 \mathrm{~nm}$. These might be due to larporteforbidden, spin allowed $d-d$ transitions but would need further investigations.

The applications of the highest ( 2 mins), $\mathrm{H}-\mathrm{Cht}-\mathrm{CuO}$ and the lowest $(0 \mathrm{~min}) \mathrm{CuO}$ (both chitosan-mediated) as catalysts for the hydrogenation of cashew kernel oil under hydrogen gas flow gave different fatty acid composition results after the process as shown in Table 1 . The table showed that oleic acid dominated the extracted oil with $84.36 \%$ by composition. However, it decreased after hydrogenation from $84.36 \%$ to $0.06 \%$ for the chitosan mediated $\mathrm{CuO}(0 \mathrm{~min})$ and to $0 \%$ for the $\mathrm{H}-\mathrm{Cht}-\mathrm{CuO}$ (2min) showing high oleic acid selectivity with increase in stearic acid composition from $4.88 \%$ to $34.97 \%$ (CuO-chitosan mediated) and to $84.76 \%$ (H-Cht$\mathrm{CuO}, 2 \mathrm{~min})$ [19].

The $0.06 \%$ oleic acid left after hydrogenation showed higher efficiency of chitosan-mediated $\mathrm{CuO}$ catalyst over previous report of non-chitosan mediated $\mathrm{CuO}$, which reduced oleic acid to $1.45 \%$. Similarly, $8 \mathrm{~min} \mathrm{H}-\mathrm{CuO}$ left $16.59 \%$ of oleic acid but was completely reduced to $0 \%$ by 2 min $\mathrm{H}-\mathrm{Cht}-\mathrm{CuO}$ [20]. Linoleic and linolenic (double and triple bonded) fatty acids were completed eliminated by the 2 mins $\mathrm{H}-\mathrm{Cht}-\mathrm{CuO}$ similar to the 8 mins $\mathrm{H}-\mathrm{CuO}$ report in literature but both differed from other findings where linoleic acid was lowered from 22 to $3-5 \%$ without increasing the stearic acid content using $8 \% \mathrm{Cu} / \mathrm{SiO}_{2}[13,20]$. Other one double bonded isomerization products e.g. myristic and paullinic not found in the raw cashew kernel oil were generated as products after hydrogenation process by both catalysts. In addition, only the chitosan mediated $\mathrm{CuO}(0 \mathrm{~min})$ produced erucic ( 1 double bonded), dihomo- $\gamma$-linolenic (3 double bonded), Arachidonic (4 double bonded) and docosahexaenoic (6 double bonded) as isomerization products. The variations in the hydrogenation products obtained could be due to larger surface area of the catalyst as a result of the multichannel/porosities created by surface engineering) of the $\mathrm{CuO}$.

Table 1. Fatty Acids composition in extracted cashew kernel oil, Hydrogenated cashew kernel oil with chitosan-mediated CuO (0 min) and H-Cht-CuO (2 mins) as catalysts, respectively.

\begin{tabular}{llll}
\hline Fatty Acid & & \% Composition after hydrogenation \\
\hline & (Cashew kernel Oil) & Chitosan mediated CuO (0 min) & H-Cht-CuO (2min) \\
\hline Hexonic $\left(\mathrm{C}_{6: 0}\right)$ & 0.06 & - & - \\
Myristic $\left(\mathrm{C}_{14: 0}\right)$ & 0.07 & 10.07 & 0.74 \\
Myristoleic $\left(\mathrm{C}_{14: 1}\right)$ & - & 3.98 & 0.92 \\
Palmitic $\left(\mathrm{C}_{16: 0}\right)$ & 0.53 & - & 2.81 \\
Palmitoleic $\left(\mathrm{C}_{16: 1}\right)$ & 0.05 & 1.49 & - \\
Stearic $\left(\mathrm{C}_{18: 0}\right)$ & 4.88 & 34.97 & 84.76 \\
Oleic $\left(\mathrm{C}_{18: 1}\right)$ & 84.36 & 0.06 & - \\
Linoleic $\left(\mathrm{C}_{18: 2}\right)$ & 8.68 & 3.63 & - \\
Linolenic $\left(\mathrm{C}_{18: 3}\right)$ & 0.13 & 6.71 & - \\
Arachidic $\left(\mathrm{C}_{20: 0}\right)$ & 0.36 & - & 10 \\
\hline
\end{tabular}




\begin{tabular}{llll}
\hline Fatty Acid & & \% Composition after hydrogenation & \\
\hline & (Cashew kernel Oil) & Chitosan mediated CuO (0 min) & H-Cht-CuO (2min) \\
\hline Paullinic $\left(\mathrm{C}_{20: 1}\right)$ & - & - & 2.13 \\
Dihomo- - -linolenic $\left(\mathrm{C}_{20: 3}\right)$ & - & 5.92 & - \\
Arachidonic $\left(\mathrm{C}_{20: 4}\right)$ & - & 2.41 & - \\
Behenic $\left(\mathrm{C}_{22: 0}\right)$ & 0.14 & 5.34 & - \\
Erucic $\left(\mathrm{C}_{22: 1}\right)$ & - & 3.34 & - \\
Docosahexaenoic $\left(\mathrm{C}_{22: 6}\right)$ & - & 0.91 & - \\
Lignoceric $\left(\mathrm{C}_{24: 0}\right)$ & 0.52 & 14.33 & - \\
Total Saturated & 6.56 & 64.7 & 98.31 \\
Total Unsaturated & 93.22 & 28.44 & 3.04 \\
Mono Unsaturated & 84.41 & 8.86 & 3.04 \\
Poly Unsaturated & 8.81 & 19.58 & - \\
\hline
\end{tabular}

The chromatograms from which the tabulated results were obtained are shown in Figure 5.
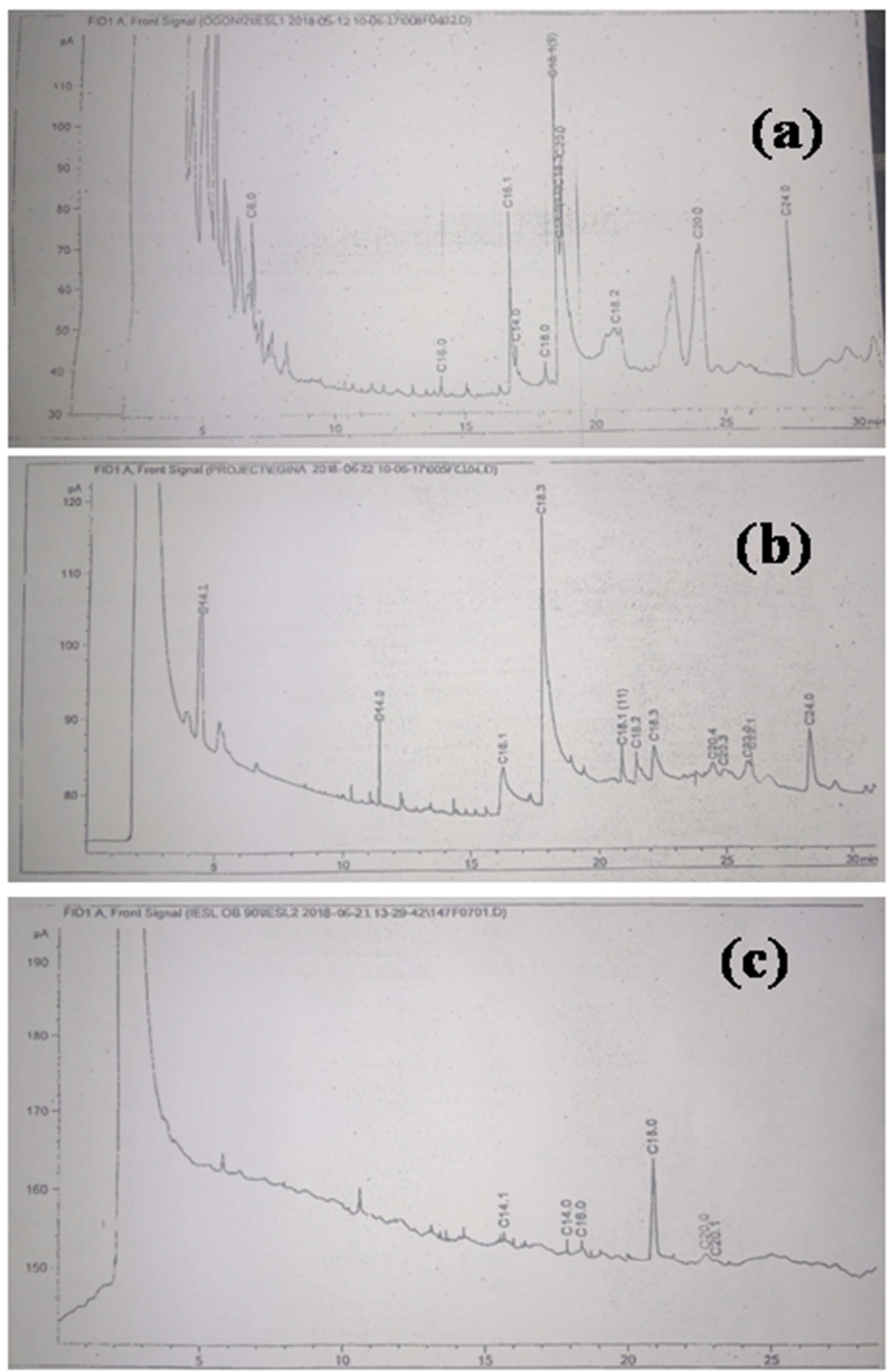

Figures 5. Chromatograms of (a) Cashew kernel oil (b) Hydrogenated cashew kernel oil using chitosan mediated copper oxide, CuO as catalyst and (c) Hydrogenated cashew kernel oil with hydrogenated chitosan-mediated copper oxide, $\mathrm{H}$-Cht-CuO (2 min) as catalyst. 
Total saturated fatty acid of $98.31 \%$ was obtained with $\mathrm{H}-$ Cht- $\mathrm{CuO}(2 \mathrm{mins})$ upon hydrogenation while that of $\mathrm{CuO}(0 \mathrm{~min})$ was $64.70 \%$. This higher efficiency can be attributed to the presence of hydrogen atoms in $\mathrm{H}-\mathrm{Cht}-\mathrm{CuO}$ (2 mins). However, the result was also higher than $79.62 \%$ reported for the non chitosan-mediated $\mathrm{H}-\mathrm{CuO}$ (8 mins) in literature [20]. In which case, larger surface area due to surface engineering might be the dominant factor as more hydrogenated catalytic sites were available for hydrogenation reactions. The result agreed with the fact that as surface area increases, the rate of chemical reaction also increases [27]. On the other hand, total saturated fatty acids of $64.70 \%$ obtained with the $0 \mathrm{~min}$ chitosan mediated $\mathrm{CuO}$ catalyst was lower than $74.21 \%$ reported for non chitosan mediated $\mathrm{CuO}$ with cashew kernel oil by the same author [20]. Therefore only the hydrogenated chitosan mediated $\mathrm{H}-\mathrm{Cht}-\mathrm{CuO}$ recorded the best catalytic activity among all including the non chitosan mediated reported in literature [20].

\section{Conclusion}

Surface engineering of $\mathrm{CuO}$ through chitosan-mediated (solgel) route has produced $\mathrm{CuO}$ with pores about 8.5 times larger than the control (nonchitosan-mediated). The ash-prepared chitosan mediated $\mathrm{CuO}$ was obtained from the reaction of copper (II) sulphatepentahydrate with green alkali (aqueous extract of ripe plantain peel ash) via sol-gel technique (chitosan-gel mediated) and heated at $550^{\circ} \mathrm{C}$ for $6 \mathrm{~h}$. The effect of the surface engineering on the time required to fully hydrogenate green chitosan-mediated $\mathrm{CuO}$ to form H-Cht$\mathrm{CuO}$ as well as the catalytic properties of both $\mathrm{CuO}$ and $\mathrm{H}-$ $\mathrm{Cht}-\mathrm{CuO}$ were also studied. The XRD reflections showed differences in peak intensities with the chitosan-mediated having broader peaks while its SEM showed pores that were 8.5 times larger than those of $\mathrm{CuO}$ (non chitosan-mediated). Similarly, UV-Vis analysis of the samples showed that the 2 mins $\mathrm{H}-\mathrm{Cht}-\mathrm{CuO}$ sample had the maximum absorptivity while $\mathrm{CuO}$ (control-chitosan mediated) had the least. The GC-MS results of fatty acids profile of cashew kernel oil before and after hydrogenation using $\mathrm{CuO}$ and $\mathrm{H}-\mathrm{Cht}-\mathrm{CuO}$ samples as catalysts showed that the oleic acid component was reduced from $84.36 \%$ to $0.06 \%$ and $0 \%$, Linoleic acid from $8.68 \%$ to $3.63 \%$ and $0 \%$ with increase in Stearic acid (saturated $\mathrm{C}_{18}$ ) from $4.88 \%$ to $34.97 \%$ and $84.76 \%$ by the $\mathrm{CuO}$ and $\mathrm{H}-\mathrm{Cht}-$ $\mathrm{CuO}$, respectively. Therefore hydrogenated chitosan mediated $\mathrm{H}-\mathrm{Cht}-\mathrm{CuO}$ (2 mins) was the better catalyst and has been recommended for use in similar hydrogenation reactions.

\section{Acknowledgements}

We wish to appreciate Raphael Ipaa and Bekee Deeue of the Department of Chemistry, Rivers State University for their technical support in the laboratory during this experiment. Worthy of mention are the roles played by Justice Uzodinma Okwechime and Bariwere Chibor of the Food Science and Technology of Rivers State University for helping with contacts for the GC-MS analysis. The authors also thank Isa Yakubu of ABU Zaria for the XRD. This research was fully funded by the authors. The authors declare that there is no conflict of interest.

\section{References}

[1] Rosengaten, F. (1984). The Book of edible nuts, $5^{\text {th }}$ edition, Walker and Co, New York, USA, pp: 45.

[2] Akinwale, T. O. (2000). Cashew apple juice: Its use in fortifying the nutritional quality of some tropical fruits. Eur. Food Res. Technol., 211: 205-207.

[3] Abitogun, A. S. and Borokini, F. B. (2009). Physiochemical parameters and fatty acid composition of cashew nut oil. Journal of Research in National Development, 7 (2).

[4] Achal, (2002). Cashew: nutrition and medicinal value. Calarado State University. Pp. 159-165.

[5] Ogunbenle, H. N. and Afolayan, M. F. (2015). Physical and chemical characterization of roasted cashew nut (Anacardiumoccidentale) flour and oil. International Journal of Food Science and Nutrition Engineering. 5 (1): 1-7.

[6] Winterhatter, P., Mearse, H., and Dekker, E. D. (1991). Fruits and Volatile Compounds of Food and Beverages. New York. Pp. 389-409

[7] Emelike, N. J. T. and Ebere, C. O. (2015). Influence of Processing Methods on the Tannin Content and Quality Charactristics of Cashew By-Products. Agriculture and Food Sciences Research. 2 (2): 56-61.

[8] Raheem, T., Oladele, E., and Amoo, I. (2015). Effect of roasting on some physiochemical and Antimicrobial properties of cashew nut (Anacardiumoccidentale) oil. International Journal of Science and Technology. 4 (12): 355-359.

[9] Ojeh, O. (1985). Cashew kernel- Another locally available source of vegetable oil. Nigerian Agricultural journal. 19/20: $50-56$.

[10] Jovanovic, D. R., Radovic, L. M., Stankovic, M., and Markovic, B. (1998). Nickel hydrogenation catalyst for tallow hydrogenation and for the selective hydrogenation of sunflower seed oil and soybean oil. Catalysis Today. 43 (12): 21-28.

[11] Fernadez, M. B., Tonetto, G. M., Crapiste, G. H., Ferreira, M. L., and Damiani, D. E. (2005). Hydrogenation of edible oil over Pd catalysts: a combined theoretical and experimental study. Journal of Molecular Catalysis A. 237 (1-2): 67-79.

[12] Ravasio, N. F., Zaccheria, and Gargano, M. (2002). Environmental friendly lubricants through selective hydrogenation of rapeseed oil over supported copper catalysts. Applied Catalysis A. 233 (1-2): 1-6.

[13] Nicoletta, R., Fedrica, Z., Michele, G., Sandro, R., Achille, F., Nicola, P., and Rinaldo, P. (2002). Environmental friendly lubricants through selective hydrogenation of rapeseed oil over supported copper catalysts. Applied Catalysis A: General, $233(1-2), 1-6$.

[14] Ermakova, M. A. and Ermakov, D. Y. (2003). High-loaded nickel-silica catalysts for hydrogenation, prepared by Sol-gel route: structure and catalytic behavior." Applied Catalysis A. Vol245: 277-288. 
[15] Plourde, M., Belkacemi, K. and Arul, J. (2004). "Hydrogenation of sunflower oil with novel Pd Catalysts supported on structural silica," Industrial and Engineering Chemistry Research. 43 (10): 2382-2390.

[16] Wright, A. T., Mihele, A. L., and Diosady, L. L. (2003). Cis selectivity of mixed catalyst systems in canola oil hydrogenation, Food Research International. 36 (8), pp: 797-804.

[17] Yecheskel, Y., Dror, I., and Berkowitz, B. (2013). Chemosphere. 93, 172.

[18] Kumar, V., Masudy-Panah, S., Tan, C., Wong, T. K. S., Chi, D. Z., and Dalapati, G. K. (2013). Copper oxide based low cost thin film solar cells, in Proceedings of the IEEE 5th International Nano-Electronics Conference (INEC'13). 443445 .

[19] Dijksra, A. J. (2002). The mechanism of the copper catalyzed hydrogenation; a reinterpretation of published data. European Journal of Lipid Science and Technology. 104 (1): 29-35.

[20] Konne, J. L. and Arinze, A. U. (2019). Hydrogenation of cashew kernel oil using green synthesized $\mathrm{CuO}$ and $\mathrm{CuO}: \mathrm{H}$ as catalyst. J. Chem. Soc. Nigeria, 44: 285-291.

[21] Aslani, A. and Oroojpour, V. (2011). CO gas sensing of $\mathrm{CuO}$ nanostructures synthesized by an assisted solvothermal wet chemical route, Physica B. Condensed Matter. 406 (2): 144149 .
[22] Wang, Y., Xu, X., Stephen, U.S and Choi, (1999). Thermal Conductivity of Nano Particle Fluid Mixture. Journal of Thermophysics and Heat Transfer. 13 (4): 474-480.

[23] Ishio, S., Narisawa, T., and Takahashi, S. (2012). $\mathrm{L}_{10} \mathrm{FePt}$ thin films with $\left[\begin{array}{lll}0 & 0 & 1\end{array}\right]$ crystalline growth fabricated by $\mathrm{SiO}_{2}$ addition-rapid thermal annealing and dot patterning of the films, Journal of Magnetism and Magnetic Materials. 324 (3): 295-302.

[24] Onubun, J. D., Konne, J. L. and Cookey, G. A. (2017). Green Synthesis of Zinc Oxide and Hydrogenated Zinc Oxide Catalysts. Material Science: An Indian Journal, 15 (4): 122.

[25] Chibor, B. S., Kiin-Kabari, D. B. and Eke-Ejiofor, J. (2018). Comparative Assessment of the Physicochemical Properties and Fatty Acid Profile of Fluted Pumpkin Seed Oil with some Commercial Vegetable Oils in Rivers State, Nigeria. Research Journal of Food and Nutrition, 2 (2): 32-40.

[26] Konne, J. L., Davis, S. A., Glatzel, S., Lees, M. R. and Hall, S. R. (2012). A new stoichiometry of cuprate nanowires. Journal of Superconductor Science and Technology, 25: 115005115011 .

[27] Faur, L. (1996). Margerine Technology. Oils and Fats Manual (Karleskind, A ed.), Vol. 2, Lovoisier Publishing, Paris. p. 951-962. 